\title{
Revolution Betrayed?
}

The Rebellion of Temporary Workers and the Chinese Cultural Revolution

\author{
Felix Wemheuer
}

December 1966 marked a unique moment in the history of state socialism. ${ }^{1}$ In that month, as China's Great Proletarian Cultural Revolution reached fever pitch, the central government in Beijing issued official permission for workers to form what it termed "rebel organizations". These were to be directed in the first place not against traditional "bad elements" or external enemies, but against "capitalist roaders" inside the Chinese Communist Party (CCP) itself. Throughout the early years of the People's Republic of China (PRC), the party had portrayed itself as the champion of the worker. Now its own leaders proclaimed that "capitalist roaders" in the leadership were in fact turncoats. To save the party, workers would have to refashion it.

Labour unrest in the early days of the Cultural Revolution centred on Shanghai. In China's largest city, a range of disadvantaged groups took advantage of a moment of extraordinary political upheaval to demand improved treatment from the state under the banner of rebellion. Among the most vocal were the so-called "temporary workers" (linshi gong) - contract labourers employed alongside the regular, permanent workforce. The number of these temporary labourers had expanded dramatically in the years after the Great Leap Forward famine (1959-1961), producing a "dual system" of labour that allowed the government to expand the urban workforce while limiting access to the generous welfare system available to permanent workers. The rebels of the early Cultural Revolution attacked contract labour as "capitalist exploitation", demanding access to the same "iron rice bowl" of benefits and job security given to their permanent counterparts.

Western scholars have generally viewed the substance of the battle over workers' rights in late 196os Shanghai in some crucial sense as subordinate to a larger game of revolutionary Realpolitik. From this viewpoint, the most important feature of the mobilization of temporary workers was not their own aims,

1 This chapter is partly based on an early version of Felix Wemheuer, A Social History of Maoist China: Conflict and Change, 1949-1976 (Cambridge: Cambridge University Press, 2019).

(C) FELIX WEMHEUER, 2021 | DOI:10.1163/9789004440395_010

This is an open access chapter distributed under the terms of the CC-BY-NC 4.o license.x wemheuer - 9789004440395 
but how these aims were instrumentalized by leftist party leaders. These leaders, so the story goes, rode the wave of workers' anger and used it to overthrow the local government in Shanghai, which was toppled in the so-called "January Storm" of early 1967 . Once the leftists had secured power, they promptly betrayed their temporary worker allies, initiating a campaign to restore production and retaining the dual system of labour almost unchanged. Some scholars have even argued for viewing the "power seizure" by rebel forces - backed as they were by the People's Liberation Army - as a restoration with Mao's blessing: a coup against worker unrest designed to curb popular demands and to demobilize out-of-control mass movements. ${ }^{2}$

The current chapter argues for a reassessment of this narrative, suggesting that although the rebellion of temporary workers did not secure an immediate change in labour relations, it did achieve what we might call a "deferred success". By 1971, the state had begun to enforce policies that allowed many temporary workers to become part of the permanent workforce, just as the rebels had demanded in 1966. To explore the background to this change, I start by introducing the role of workers in the state socialist economy and the dual system of labour. I then examine the conflicts created by the massive reduction of the permanent urban workforce in the aftermath of the early 196os' famine, as well as the concomitant expansion of contract labour. It was these conflicts that came to the surface so dramatically in the Shanghai worker rebellion of late 1966. I follow earlier scholars in acknowledging that the new municipal government installed by the "power seizure" of 1967 demobilized this movement, rather than fulfilling its promise. I depart from earlier accounts, however, in stressing the massive increase of workers and staff in the urban stateowned and collective sectors of the economy in the later years of the Cultural Revolution. Statistical surveys make plain that far from continuing to shrink, the urban "iron rice bowl" expanded significantly in the late Mao era.

Workers in Maoist China enjoyed a higher level of prestige than any other officially recognized class. In the language of the CCP, "worker" (gongren) was a relatively exclusive term, referring only to permanent employees of industrial work units, who were lauded by the party as "masters of the country". In the

2 For example, see Andrew Walder, Chang Ch'un-ch'iao and Shanghai's January Revolution (Ann Arbor: Cambridge University Press, 1978); Yiching Wu, The Cultural Revolution at the Margins: Chinese Socialism in Crisis (Cambridge, MA: Harvard University Press, 2014), 139-140. 
early days of the PRC, this was a highly select group: in 1951, Zhou Enlai estimated that there were three to four million industrial workers across the whole of China, accounting for less than one per cent of the population. ${ }^{3}$ Most modern industry was concentrated in Shanghai and Manchuria.

Chinese labour's relationship with the state had long been fraught. In the first half of the 1920s, labour movements had begun to develop in the cities, and large strikes had broken out. Antagonism between workers and the authorities reached a peak in 1927, when the nationalist government of the Guomindang (GMD) massacred large numbers of communists and labour activists. Organized labour in China never fully recovered from this blow. Later, urban labour movements played only a minor role in the Chinese Civil War and the 1949 revolution. As the People's Liberation Army swept through China's cities, the CCP's outreach to workers was limited to calls to maintain production and defer to the party's representatives. Following the establishment of the PRC, the CCP restricted representation of workers to the party-backed All-China Federation of Trade Unions. In the first years of the new China, urban unemployment remained high.

A number of scholars have pointed out continuities between the CCP's approach to managing the urban workforce and that adopted by the GMD before 1949. The establishment of official labour unions and workers' militias under party leadership were both nationalist innovations, as was the system of work units that the GMD had set up during the Anti-Japanese War. ${ }^{4}$ In the years after 1949, the party emphasized increased production, work discipline and the mutual benefits for labour and capital in a mixed economy; goals that differed little from those of corporatist regimes across the globe. Evidence from case studies adds to the impression of continuity with the old regime. To take one example, archival research on the silk industry in the city of Wuxi has shown that male overseers from the pre-1949 period, some of whom were known to have viciously beaten female workers, were still in charge of shop floors several years after the communist victory. ${ }^{5}$ Workers who had taken the promise of

3 Zhou Enlai, "Guanyu zhishifenzi de gaizao wenti", in Jianguo yilai zhongyao wenxian xuanbian, vol. 2, ed. Zhongyang wenxian chubanshe (Beijing: Zhongyang Wenxian Chubanshe, 1992) (quoted as JGYL in the following notes), 446.

4 For details, see Elisabeth Perry, "Masters of the Country? Shanghai Workers in the Early People's Republic", in Dilemmas of Victory: The Early Years of the People's Republic of China, ed. Jeremy Brown and Paul G. Pickowicz (Cambridge, MA: Harvard University Press, 2007), 78; Mark W. Frazier, The Making of the Chinese Industrial Workplace: State, Revolution and Labor Management (Cambridge: Cambridge University Press, 2002).

5 Robert Cliver, Red Silk: Class, Gender, and Revolution in China's Yangzi Delta Silk Industry (unpublished manuscript, Cambridge, MA: forthcoming). 
"liberation" seriously were often disappointed that so little had changed, and many believed that the revolution had failed to live up to its early promise. In Shanghai, labour unrest and strikes in the early years of the PRC put the government under sustained and unwelcome pressure.

Against this background, how are we to understand the CCP's lofty assertion that, under its rule, workers were "masters of the country"? The claim makes sense only in the context of the party's Marxist-Leninist ideology. Karl Marx had argued that prior to the proletarian revolution, which would begin the transition to socialism, the bourgeoisie would seize power from the feudal classes and replace the system of feudal exploitation with one of capitalist exploitation, of which the bourgeoisie itself would be the primary beneficiary. ${ }^{6}$ The working class would then lead a second revolution, which would result not only in the liberation of the workers, but - through the overthrow of the capitalist system - of humanity as a whole. Thus, the proletariat was the ultimate liberating class, expected not only to seize power, but also to abolish class structures and exploitation entirely.

During the Chinese revolution of 1949, peasants had played a much more important role than the urban population. Urban workers, however, represented the future of the communist cause and were a key element of the industrialized, socialist country the CCP was seeking to build. In line with the rest of the socialist bloc in Eastern Europe, the party in the 1950s saw workers as the most progressive class. Industrial labourers worked with advanced technologies in the factories of urban China, and their social relations were thought to be based less on kinship structures than on class solidarity, built through collective experiences of strikes and the class struggle on the shop floor. The growth in the number of industrial workers in state industries after 1949 therefore amounted to an expansion of the pool of future socialists. After private ownership of land and means of production were abolished, everyone was to be a worker.

In short, the CCP's descriptions of "mastery of the country" grew out of the workers' theoretical role in the construction of socialism and the expectation that as the new China modernized, the working class would inexorably expand with it. On these terms, "mastery" did not necessarily equate to governing authority. In fact, the party constitutions of 1945, 1969 and 1973 defined the CCP not as the servant of the working class but as its "vanguard". ${ }^{7}$ The party was the

6 Karl Marx and Friedrich Engels, Manifesto of the Communist Party (1848), https://www.marxists.org/archive/marx/works/1848/communist-manifesto/cho1.htm\#007 [1 March 2017].

7 Zhongguo geming bowuguan, ed., Zhongguo gongchandang dangzhang huibian (Beijing: Renmin chubanshe, 1979), 46, 206, 212. 
mouthpiece, not of the transient, subjective desires that workers might themselves express, but of their deeper, objective interests. Building a communist future required the party to inculcate "class consciousness" into the workers, encouraging them to act according to the laws of historical development that would lead humanity towards communism.

Hand in hand with this went the need to strengthen the proletarian character of the party, a goal that required continual struggle against the negative ideological influence of the petty bourgeoisie and peasant smallholders. Workers had to be systematically trained to become cadres and leaders to replace officials from the old regime. The CCP under Mao adopted a narrative that viewed purging "class enemies" and fighting against leftist or rightist deviation as a way for the party to purify itself. While only the most advanced and revolutionary workers could become party members, all the workers in state-owned enterprises were automatically enrolled in official labour unions. These were the "schools of communism" that would educate and raise the political consciousness of all workers, acting - in Lenin's formulation - as the link between the vanguard and the masses. ${ }^{8}$ This link worked in both directions. On the one hand, the best trade union talent could be recruited into the party-state apparatus. On the other, unions were expected to implement government policies, enforce labour discipline and organize welfare in work units.

Despite their lack of independent representation and political power, many workers benefited significantly from the socialist transformation. For millions, the founding of the PRC brought safe jobs and entitlement to welfare. The number of Chinese citizens enjoying official worker status rose dramatically between 1949 and 1957, as relatively lax controls on internal migration allowed the urban population to boom. Over this period, the population of China's cities and towns rose from 57.6 to 99.4 million, ${ }^{9}$ while the workforce in stateowned enterprises tripled from eight to 24 million. For those who managed to become part of the permanent workforce, the PRC's promise of upward social mobility was a genuine reality. For the rest of their life, they were entitled to secure employment, welfare, food rations, free health care and cheap housing. The official retirement age was 55 for women and 60 for men, and workers could be reasonably confident that at least one of their children would be able to join their work unit in adulthood. Beyond the state sector, the workforce in collectively-owned enterprises also expanded rapidly; from 230,000 in $195^{2}$

8 V. I. Lenin, The Trade Unions, The Present Situation and Trotsky's Mistakes (1920), https://www. marxists.org/archive/lenin/works/1920/dec/3o.htm [18 September 2017].

9 Lu Yu, Xin Zhongguo renkou wushi nian, vol. 1 (Beijing: Zhongguo renkou, 2004), 633. 
to 6.5 million people in $1957 \cdot{ }^{10}$ As was intimated above, the work unit system was not an invention of the CCP, but had its origins in Republican China and the Soviet Union. Nevertheless, it was under the CCP's rule that almost the entire urban population became part of the system, with social life, sport and cultural activities all collectively organized by work units for their members. For those on the inside, the new regime brought tangible benefits, and these success stories of the early PRC should not be overlooked.

However, it should not be forgotten that only a small percentage of the population ever tasted the sweetness of the "iron rice bowl". During the Mao era, it remained beyond the reach of the entire rural population. To use the contemporary phrase, almost the whole of China beyond the cities was "outside the system" (tizhiwai), without access to state-backed entitlements. Peasants became members not of work units with defined welfare schemes, but of agricultural cooperatives (established nationally by 1956) and then, by 1958, of People's Communes. Their standard of living depended on the production output of their collectives, and they were not entitled to grain rations or statemandated welfare. Mao was among a number of leaders to argue that the country was too poor for the urban welfare state to be expanded to the villages. Only by focusing on industrial development could China escape backwardness and poverty, and welfare for all would have to wait. ${ }^{11}$ By 1958, the government had established a system of household registration (hukou) that divided China into "agricultural" and "non-agricultural" populations. An important goal of this innovation was to limit and control rural-to-urban migration. Agricultural hukou holders who left their villages without permission from the authorities had no legal access to ration cards, employment, schooling or housing in the cities. In Maoist China, life in the state-subsidized urban world was a privilege, and the government reserved the right to decide who was entitled to that privilege and who was not.

Significant inequalities existed within urban society as well. At one end of the scale was the permanent workforce of the state-owned enterprises, which existed "inside the system" (tizhinei), with high job security and generous benefits. Lower down the pecking order were workers in the collective sector, who generally earned reasonable salaries, but had reduced access to housing, medical care, social security and pensions. Below them sat a group of more

10 Zhonggong zhongyang shujichu yanjiushi lilunzu, ed., Dangqian woguo gongren jieji zhuangkuang diaocha ziliao huibian, vol. 2 (Beijing: Zhonggong zhongyang dangxiao chubanshe, 1983), 105-107.

11 Mao Tse-tung, Ausgewählte Werke, vol. v (Beijing: Verlag für fremdsprachige Literatur, 1978), 141. 
or less casual labourers, known either as "temporary workers" (linshigong) or "contract workers" (hetonggong). This group, who enjoyed only minimal protection, comprised people recruited by work units for seasonal tasks or as additional labour to fulfil short-term production goals. Many were from a peasant background, and their stay in the urban world was strictly limited. In most cases they retained their original, agrarian household registration, meaning that they were expected to return to their village after the expiration of their contract. In addition to the rural labourers, urban women made up a large proportion of the temporary workforce. Particularly in industry, contract workers were often drawn from among the wives of male permanent workers. This gendered dimension of the dual system of labour needs to figure prominently in any analysis. ${ }^{12}$

Divisions between the permanent and non-permanent workforce were an important feature of labour conflict throughout the PRC's twentieth-century history; from the wildcat strikes and unrest of 1956, through the early Cultural Revolution and even into the $198 \mathrm{os}^{13}$ All through the pre-reform period, temporary workers' demands for access to the "iron rice bowl" met with a lack of solidarity from permanent workers, who generally defended the status quo. The early Cultural Revolution saw this particular form of intra-class conflict reach its zenith, and to understand why, we need to examine the central government's labour policy in the two years following the Great Leap Famine (1961-1963).

\section{2 Famine Recovery: The Origins of Conflicts over Temporary Labour}

In 1958, the PRC government launched the Great Leap Forward, aiming to industrialize China with unprecedented speed. The subsequent two years saw a massive expansion of the urban population and the workforce in the stateowned and collective industries. Despite the establishment of a nationwide household registration system, between 1957 and 196o the population of China's cities and towns increased by over 30 million, and industrial enterprises continued to recruit labour power from the countryside to fulfil the ambitious targets of the Great Leap. ${ }^{14}$ This trend meant that a smaller number of agrarian

\footnotetext{
12 For more details see Wemheuer, A Social History of Maoist China, 132-134, 270-272.

13 Elizabeth Perry, Challenging the Mandate of Heaven: Social Protest and State Power in China (Armonk: Cambridge University Press, 2001), 170-295.

$14 \mathrm{Lu} \mathrm{Yu,} \mathrm{Xin} \mathrm{Zhongguo} \mathrm{renkou} \mathrm{wushi} \mathrm{nian,} 633$.
} 
producers had to feed a much larger urban population, even as government mismanagement and adverse weather conditions began to put the harvests under pressure.

As the Great Leap Famine began to bite in 1959, the countryside bore the brunt of the pain. State control of grain supplies under the "unified purchase and sale" (tonggou tongxiao) system meant that the authorities could continue to appropriate as much grain as they saw fit, even under starvation conditions. The central government chose to use this power to protect urban grain consumers at the expense of rural farmers. Remarkably, net grain procurement as a proportion of the harvest actually increased after 1956, rising from 14.9 per cent to 28 per cent in 1959, followed by a decrease to a still elevated 21.5 per cent in 1960, at the peak of the rural famine. ${ }^{15}$ This supposedly surplus grain was used to feed the expanding urban population and rural labour power outside of agriculture, and some of it was also exported.

Even this increased procurement could only protect the cities for so long. In the winter of 1960, urban grain stocks began to run low, including in key cities such as Beijing and Shanghai. Unwilling to countenance the prospect of a rural famine reaching the major urban centres, the government had little choice but to reverse many of the central policies of the Great Leap. In order to reduce the pressure on the supply system, programmes were launched to reduce the number of people entitled to welfare; that is, the urban population in general and the industrial workforce in particular. ${ }^{16}$

\section{Reduction of the Urban Population and Workforce}

The architects of this "readjustment" of the national economy were the senior party officials, Chen Yun and Li Xiannian. Both men argued for a reduction of the urban workforce and for the import of grain in order to restore the balance between urban consumers and net grain producers in the countryside. Chen in particular believed that the uncontrolled growth of the urban population had been the major reason, not only for the enormously destructive Great Leap Famine, but also for smaller disruptions to the grain supply in 1953, 1954 and

15 With regard to production and procurement, see "Zhonghua renmin gongheguo nongye bu jihuasi", ed., Zhongguo nongcun jingji tongji daquan 1949-1986 (Beijing: Nongye chubanshe, 1989), 410-411.

16 For more details, see Felix Wemheuer, Famine Politics in Maoist China and the Soviet Union (New Haven: Yale University Press, 2014), 142-147. 
$1957 \cdot{ }^{17}$ Fewer consumers entitled to urban ration cards would mean reduced pressure on the state to extract grain from the countryside to feed the cities. Not only would this rebalancing increase the number of agricultural workers, but crucially it would also reduce the overall amount of grain needed for the country as a whole, since much smaller rations were provided to rural residents than those with an urban household registration were entitled to. Along with population transfers, Chen also argued for the restoration of plots of land for private household use within the structure of the People's Communes. In many places, these had been abolished during the collectivist fervour of the Great Leap, and Chen believed that reintroducing them would allow those who were sent back from the cities to be self-supporting. ${ }^{18}$

Taking into account the volume of agricultural production and the number of urban consumers of trade grain, Chen estimated in 1962 that 20 million people needed to be sent back to the countryside from the cities and towns (chengzhen). Recent migrants who had come to urban areas during the Great Leap became the main target of the "downsizing" policy. In total, 26 million people were moved to the countryside between late 1960 and $1963 .{ }^{19}$ Table 8.1 outlines the reduction in the workforce of the state-owned enterprises (also known as "ownership by the whole people"): 8.7 million in 1961 and a further 8.6 million in 1962. By contrast, the number of workers in collectively-owned enterprises, where entitlements were more restricted, actually increased slightly during those years. Attempts to assess the exact effect of Chen and Li's recovery plan on the urban population are complicated by the fact that statistics from the period almost invariably include within the category of urban residents, segments of the suburban population that were actually engaged in agricultural production. Taking this statistical anomaly into account, it seems probable that non-agrarian urban residents never constituted more than 20 per cent of the Chinese population during the Mao era, although within this low percentage, the reforms do appear to have had a significant effect. The non-agrarian urban population's proportion of the national total decreased during the $196 \mathrm{os}$, from 14 per cent in 1964 to 12.9 per cent in 1968; a figure it did not exceed until after Mao's death in $1976{ }^{20}$ The government effectively capped the population of

17 "Shangyebu dangdai Zhongguo liangshi gongzuo bianjibu", ed., Dangdai Zhongguo liangshi gongzuo shiliao, vol. 1 (Baoding: Hebei sheng gongxiaoshe Baoding yinshuachang yinshua, 1989), 314 .

18 Chen Yun, "Dongyuan chengshi renkou xiaxiang", in JGYL, vol. 14, 374.

$19 \mathrm{Lu} \mathrm{Yu,} \mathrm{Xin} \mathrm{Zhongguo} \mathrm{renkou} \mathrm{wushi} \mathrm{nian,} 594$.

20 Yuan Yongxi, ed., Zhongguo renkou zonglun (Beijing: Zhongguo caizhengjingji chubanshe, 1991), 277 . 
the towns and cities, limiting the number of people who were entitled to food rations, welfare and non-agrarian jobs. The leadership of the CCP had learnt important lessons from the famine.

These measures alone, however, were still not sufficient to stabilize the food supply system in the post-famine years. Reform had to be coupled with immediate relief via grain imports. As Chen Yun argued: "If we import grain, we can take less from the peasants, stabilize their attitude towards production, and raise the enthusiasm of the peasants for production. If we take two or three years to develop agricultural production, the problems of the internal market can be solved". ${ }^{21}$ Between 1961 and 1965, China imported on average five million tons of grain each year; net imports stood at around 4.18 million tons per annum..$^{22}$ Rather than being sent to famine-hit rural areas, this grain was used to supply Beijing, Tianjin, Shanghai and Liaoning. All four areas were part of the urban supply system administered directly by the central government, and the imports therefore constituted a form of indirect famine relief, reducing the burden on peasants to meet grain quotas and allowing more grain to remain in the villages. By opting for this method of relief, the government avoided imported grain passing through the hands of rural officials, thereby reducing the risk of fraud and misappropriation. From 1962, quotas for grain procurement had stabilized enough to bring rural communities out of famine. Strict enforcement of the household registration system helped maintain the balance between agricultural production and urban consumption.

Although the austerity policies and downsizing of the urban population were necessary, they nevertheless had a deleterious effect on morale in the cities. Little is known about how ordinary people reacted to the programme of downsizing, or about differences in responses between rural and urban China. It seems safe to say, however, that many would have agreed with the words of one worker in Shaanxi: "The capitalists call it going bankrupt, we call it stopping production. The capitalists call it firing, we call it being sent down. The capitalists call it unemployment, we call it [workforce] reduction. In any case, we have no jobs and it is still the same as in capitalist countries". ${ }^{23}$ Work units throughout China were given quotas for reducing their workforce. Some urban residents tried to avoid being sent back to the countryside by petitioning the local government. Most petitioners argued that they were sick, pregnant or

21 Quoted in Jin Chongji, ed., Zhou Enlai zhuan, vol. 4 (Beijing: Zhongyang wenxian chubanshe, 1998), 1565 .

22 Luo Pinghan, Da qian xi: 1961-1963 nian de chengzhen renkou jing jian (Nanning: Guangxi renmin chubanshe, 2003), 118.

23 Quoted in Luo Pinghan, Da qian xi,223. 
TABLE 8.1 Total number of employees in state-owned and collectively-owned enterprises, 1960-1965 (all figures in millions)

\begin{tabular}{|c|c|c|c|c|c|}
\hline \multirow[t]{3}{*}{ Year } & \multirow{3}{*}{$\begin{array}{l}\text { Total } \\
\text { workforce }\end{array}$} & & & & \\
\hline & & \multicolumn{2}{|c|}{ Ownership by the people } & \multicolumn{2}{|c|}{ Collective ownership } \\
\hline & & Workforce & $\begin{array}{l}\text { Year-on-year } \\
\text { increase }\end{array}$ & Workforce & $\begin{array}{l}\text { Year-on- } \\
\text { increase }\end{array}$ \\
\hline 1960 & 59.69 & 50.44 & 4.83 & 9.25 & 2.11 \\
\hline 1961 & 51.71 & 41.74 & -8.70 & 10.00 & 0.75 \\
\hline 1962 & 43.21 & 33.09 & -8.65 & 10.12 & 0.12 \\
\hline 1963 & $43 \cdot 72$ & $3^{2.93}$ & -0.16 & 10.79 & o. 67 \\
\hline 1964 & 46.01 & 34.65 & 1.72 & 11.36 & 0.57 \\
\hline 1965 & 49.65 & $37 \cdot 3^{8}$ & 2.73 & 12.27 & 0.91 \\
\hline
\end{tabular}

SOURCE: ZHONGGONG ZHONGYANG SHIJICHU YANJIU LILUNZU (ED.), DANGQIAN WOGUO GONGREN JIEJI ZHUANGKUANG DIAOCHA ZILIAO HUIBIAN (BEIJING, 1983) VOL. 2, 105-106

had to provide care for dependent family members, while others threatened to commit suicide if they were not allowed to remain in the cities. ${ }^{24}$ The fact that targets for staff reductions were generally met suggests that these strategies tended to be ineffective. The central government's ability to enforce a largescale population transfer hard on the heels of the famine crisis reflects the remarkable capacity of the early PRC state.

Little research has been carried out into how the arrival of returnees from the cities affected the villagers who had stayed behind. In contrast to the "sentdown youth" of the Cultural Revolution, many people who were hit by the downsizing of 1962 and 1963 were recent migrants who had left the countryside only a few years earlier and had remained familiar with agricultural production. They were not strangers in their home villages. Nevertheless, it remains an open question as to whether the returnees were welcomed as additional labour power or seen as competitors for scarce food. What is certain, however, is that the countryside finally recovered under the influence of the CCP's new

24 For more details, see Jeremy Brown, City versus Countryside in Mao's China: Negotiating the Divide (Cambridge: Cambridge University Press, 2012), 86-99. 
policies. To achieve this recovery, the government sacrificed its push for rapid industrialization, which prior to 1961 had been primarily driven by imports of foreign technology financed by exports of grain. The state also raised the price it paid for grain to incentivize production, but in order to keep the peace in urban areas, the sale price remained stable. The losses from what was effectively a massive subsidy programme would be a burden on the state's budget for the next two decades. ${ }^{25}$

\section{Reforms in the Labour Market: Enforcing Dualism}

In addition to population transfers, another major element of the central government's recovery programme was a change in the recruitment of urban labour. Between 1962 and 1965, the CCP established the already-mentioned dual system in the labour market, as well as an equivalent system in education. The reasoning behind this move was simple. Many factories required new workers in order to meet their post-famine production targets. However, the central government was reluctant to increase the number of people on the state's payroll; a move that had backfired so spectacularly during the Great Leap. Between 1960 and 1963, the workforce in state-owned enterprises had decreased from 59 to 43 million, releasing some of the pressure on the urban welfare system. Some of these losses had been absorbed by the collective enterprises, where the workforce had increased from 9 to 11 million, but the overall number of workers had still dropped, and more labour had to be found from somewhere.

It was soon realized that one way to control government spending while enlarging the workforce was to allow an increase in the number of temporary workers. Short-term work had existed alongside lifetime employment since 1949. A decision by the Labour Department in 1959 had distinguished between three forms of urban work: long-term employment, temporary contract work undertaken by urban workers, and a system of "peasant-workers" recruited from the countryside for short-term work in factories. ${ }^{26}$ Now, the government dramatically expanded the number of workers in the latter two categories. "Peasant-workers" were an especially useful resource, since although their

25 Terry Sicular, "Grain Pricing: A Key Link in Chinese Economic Policy", Modern China, 14, no. 4 (1988): 461-463.

26 Zhongguo shehui kexueyuan and zhongyang dang'anguan, ed., 1958-1965 Zhonghua renmin gongheguo jingji dang'an ziliao xuanbian. Laodong jiuye he shouru fenpei juan (Beijing: Zhongguo caizheng jungji chubanshe, 2011), 5 . 
wages were higher than the average rural income, they remained poorly paid compared with regular urban workers.

It was clear from the outset that peasant-workers were not to be allowed to become part of the permanent urban workforce. A 1965 report by the Labour Department about the situation in Sichuan Province expressed concern that if wages for young peasant-workers were set too high, they would cause tension in the villages after their return. The report also recommended that production brigades should be able to claim compensation for work lost as a consequence of members taking temporary jobs outside agriculture. ${ }^{27}$ Both these conclusions rested on the assumption that a peasant-worker was and would remain part of his or her rural community, with no prospect of earning admission to the urban world. Although temporary workers were a minority, they were nevertheless a significant part of the urban workforce in the 196os. By the end of 1965, China had over 33 million permanent workers and 3.18 million urban contract workers; an increase of 540,000 over the previous year. Another two million people were employed as peasant-workers. A contemporary report by the State Statistics Bureau praised the dual labour market for allowing urban work units to replace many permanent workers with temporary staff. ${ }^{28}$

In expanding the dual labour market, the government never planned to abolish the "iron rice bowl", but it did intend for a significant number of workers to be temporarily employed and denied access to the welfare state. From 1964, President Liu Shaoqi was an important advocate for the dual system in the labour market and in education. In a speech on the topic, Liu argued that while the iron rice bowl was the gold standard, it introduced problems by making it difficult to "withdraw" workers; that is, to fire them. For seasonal tasks, temporary employment was a more desirable route. As Liu put it, "If there is work, they come. If there is not, they can go home". ${ }^{29}$ Liu argued against future increases in the permanent workforce, and he even suggested that entire sectors might become the exclusive preserve of temporary workers. Discussing the mining industry, Liu noted that life underground could lead to severe health problems, and he proposed that workers should be recruited only to work in the mines for a few years before being mandatorily discharged. While he was careful to frame his argument in terms of workers' interests, "mandatory discharge" would have had the convenient side effect of turning a whole industry into short-term contract work. Liu's speech was rooted above all not

\footnotetext{
27 Ibid., 400.

28 Ibid., 459 .

29 Liu Shaoqi, "Guanyu liang zhong laodong zhidu he liang zhong jiaoyu zhidu”, YGYL, 19 (1991): 174 .
} 
in the socialist logic of worker entitlements, but in the government's desire to reduce costs.

In sum, the years between 1962 and 1966 saw a deepening of the urban-rural divide, resulting from a deliberate reduction in the number of people entitled to access the urban welfare state and stricter enforcement of the hukou registration system. A side effect of these policies was to limit social mobility for the rural population. Within the cities, the gap between the permanent and temporary workforce also widened. Nevertheless, the party leadership remained united behind the new measures, and it is notable that Mao never questioned the hukou system in his lifetime, or the various programmes to reduce the urban population.

\section{The Worker Rebellion during the Cultural Revolution}

Before examining the rebellion of temporary workers in greater detail, it may be useful to set out, in brief, the events of the first months of the Cultural Revolution, when labour unrest was at its peak.

Shanghai was at the centre of labour unrest during the early Cultural Revolution, but the movement as a whole began in June 1966 in Beijing. Its earliest manifestation - the student Red Guards, who emerged in middle schools and universities that month - was dominated by the children of high-ranking cadres. These young people focused their attacks on teachers and members of the old cultural and intellectual elites. Mao gave his blessing to this movement, but from August 1966 the agenda and targets began to change, as other students, and eventually workers, entered the fray. Some scholars describe this period as the "People's Cultural Revolution", which lasted until a conservative backlash began in earnest in January $1967 .^{30}$

A few weeks into the movement, on August 18 1966, the CCP Central Committee issued a decision on the direction of the Cultural Revolution, marking a shift from the purge of cultural elites to an attack on "capitalist roaders in power inside the Communist Party". The decision emphasized the right to form mass organizations. ${ }^{31}$ One of the first leading figures to come under pressure was President Liu Shaoqi, who was finally purged that autumn. The

$30 \quad$ For example, see Liu Guokai, "Lun renmin wenge (yi) - wei wenge sishi zhounian er zuo", Epoch Times, 12 December 2005, http://www.epochtimes.com/gb/5/12/30/n1171757.html [3 December 2015].

31 "Decision of the Central Committee of the Chinese Communist Party concerning the Great Proletarian Cultural Revolution" (8 August 1966), https://www.marxists.org/subject/china/peking-review/1966/PR1966-33g.htm [19 June 2017]. 
major accusation against Liu was that he had suppressed the student movement in the summer by sending work teams to the universities to curb the Red Guard's activities. Many students who had been labelled as "rightists" or "counterrevolutionaries" by the work teams or school authorities during that period fought for rehabilitation. Under the slogan "rebellion is justified", all manner of grievances against local party apparatuses began to be aired. Revolutionary groups took the interpretation of Mao Zedong Thought, the core of CCP ideology, into their own hands. Mass organizations published unauthorized transcripts of speeches and quotations by Mao and other central leaders in their newspapers.

As time went on, conservative mass organizations, also called the "protectingthe-emperor faction", were formed to defend local party committees against the rebels. Local cadres mobilized CCP and Communist Youth League members, labour activists and loyal workers. Some elite "old" Red Guards from the early days of the Cultural Revolution had grown disillusioned, as they watched the movement turn against their parents from August onwards, and they therefore supported the conservatives. The move to restore order was met, in October, by a new campaign against "the reactionary bourgeois line", meaning the suppression of the rebel movement by officials. Widespread revolt broke out against cadres all over the country. As dissent concerning local authorities grew, the Central Committee finally allowed workers to join the Cultural Revolution, as long as they did so outside of work hours. As a result, the movement spread to the whole urban population.

During the "People's Cultural Revolution", the government's ability to control the fledgling rebel movement was tested. Young people who had been sent down to the countryside under the centrally mandated "Up to the Mountains, Down to the Villages" programme demanded to be allowed to return to the cities. Many of those who had suffered in the campaigns of the pre-1966 period sought rehabilitation, and disadvantaged groups "hijacked" the rebellion to promote their own economic and political interests. ${ }^{32}$ In Shanghai in particular, temporary workers were a major force in the Cultural Revolution, calling for secure, permanent posts in the state-owned enterprises. The first attacks on the local authorities in Shanghai were student led, but in November 1966, workers began to press for their own right to form city-wide rebel organizations. Their request was refused, and on November 10, around 1,000 workers led by Wang Hongwen's Shanghai Revolutionary Rebel Worker Headquarters commandeered a train and set out for Beijing to petition the central 
government. They were halted at Anting on the outskirts of Shanghai, and their refusal to disembark resulted in all traffic on the Beijing line being halted for over 31 hours. As the Anting Incident unfolded, the mayor of Shanghai, Cao Duiqi, demanded that the workers immediately return to their units. Wang's rebels refused to back down until their demands had been met: the recognition of their mass organizations and an acknowledgement that their actions were legal. They also demanded public criticism of Cao Duiqi and the handling of the conflict by the higher authorities. ${ }^{33}$ Zhang Chunqiao, the negotiator sent by the Cultural Revolution Leading Group from Beijing, eventually signed off on the rebels' demands with Mao's support.

The Anting Incident showed that grassroots pressure could persuade the CCP leadership to ally with rebels against local party authorities, even in the country's most important industrial city. Only a few thousand workers had joined the initial Shanghai rebellion. After the success in Anting, however, rebel workers' organizations in other cities were emboldened, and many called for official recognition. On December 12, the Central Committee declared the right of workers to participate in the Cultural Revolution and to form their own mass organizations, with the proviso that production should not be disturbed. ${ }^{34}$ For the first time since 1949, the central leadership recognized independent workers' organizations that were not integrated into the state apparatus. This might have represented an opportunity for progress in workers' rights, but the change did not last for long. ${ }^{35}$ It should be noted that many workers remained suspicious of the rebel forces: between November and late December, the party leadership in Shanghai was able to mobilize significant numbers of workers in a counterattack by the conservative Scarlet Guards. Another critical point to note is that the students' and workers' rebel movements drew on very different demographics. In contrast to many of their student counterparts, rebel workers often had good class status, and more than a few had been party members before 1966. From August 1966 onwards, many of the student rebels were the children of intellectuals and capitalists - victims of previous purges who had much to gain from a shake-up of the political order. By contrast, industrial workers "inside the system" were one of the most privileged groups in China.

33 Li Xun, Geming zaofan niandai: Shanghaiwengeyundong shigao, vol. 1 (Hong Kong: Oxford University Press, 2015), 333.

34 "Zhonggong Zhongyang guanyu zhua geming, cu shenchan de shitiao guiding (cao'an)", (9 December 1966), in The Chinese Cultural Revolution Database, ed. Song Yongyi (Hong Kong: Universities Service Centre for China Studies, The Chinese University of Hong Kong, 2006). 
Why, then, did permanent workers participate at all? Without doubt, some had grievances against the system of one kind or another, and the Cultural Revolution offered a rare opportunity to air them. In fact, however, the main demand of the rebel permanent workers in Shanghai was for the right to participate in the Revolution at all, since this would offer them the possibility of improving their political status through performance. In Maoist China, the access to party or army membership, higher education and social status within society was linked to class status, family background and political performance. People could do little to change their official class status or family background, but could improve the party's evaluation of their performance by engaging in political activism. The extent to which rebellion was about raising one's political status was made clear after the movement, spearheaded by Wang Hongwen's Rebel Workers' Headquarters, took over power from the municipal authorities in January 1967 . From this point on, activists from the heady days of the Anting Incident began to claim the label of "old rebels", meaning that they had attacked the authorities when it was dangerous to do so and the fate of the rebel groups had remained uncertain. This privileging of early participation recalled the boast of "revolutionary cadres" from the pre-1949 days, of having joined the party before its victory was assured. The Cultural Revolution offered those born too late to be revolutionaries the chance to perform their own acts of political daring. For permanent workers therefore, the main goal was participation rather than any critique of categorization or of the system of class status.

The foregoing paragraphs have captured only a snapshot of the multiple competing interests at work among the conservative and rebel factions during the "People's Cultural Revolution". For Mao and the other ссP leaders, the complex, shifting alliances of this period presented a serious problem. The leadership was left in the unenviable position of trying to propel some aspects of the movement while at the same time limiting others. Leaders remained keen to harness the energies of the masses, but at the same time they worried that widespread strikes and factional infighting could put economic development at risk.

More seriously still, from the Party Central's perspective, the attempts of rebel organizations to coordinate at the national level represented a potential challenge to the CCP's monopoly on state power. This was - as it remains to this day - a line that could not be crossed. By the end of 1966, the central government had halted the so-called "big link-up" of rebel groups, as well as the free train travel that had allowed Red Guards to easily connect with groups far from home. The slogan of the day, the double-headed "grasp revolution, promote production", gave some indication of the balance the party leadership 
was attempting to strike. Temporary workers, soldiers on active duty, public security staff and labour camp inmates were banned from forming their own rebel organizations; the occupation of archives and public security offices was also outlawed. The "People's Cultural Revolution" came to an end, and the rebel organizations shifted their focus to a goal acceptable to the leadership: "seizing power" from suspect local officials.

With this general overview of the "People's Cultural Revolution" in mind, we now turn more specifically to the rebellion of temporary workers. As we have seen, the expansion and downsizing of the urban workforce between 1958 and 1962 had been a major source of conflict. In the winter of 1966 , temporary workers used the Cultural Revolution and the ongoing critique of Liu Shaoqi to attack the system of contract labour as an anti-socialist form of exploitation. Liu was accused of masterminding the nationwide expansion of this system from 1964 onwards, with the aim of splitting workers into two classes and depriving temporary workers of their political rights. Particularly in Shanghai, temporary workers carved out a strong position within the rebel movement, and they used this platform to demand to be made part of the permanent workforce.

By late 1966, the old municipal government of Shanghai had given in to demands including higher wages, access to welfare and public housing, and financial support for a new "big link-up" to exchange revolutionary experiences with groups elsewhere in China. By this stage, strikes had already caused parts of certain industries to collapse. ${ }^{36}$ In what became national news, on 26 December 1966 in the Great Hall of the People in Beijing, Jiang Qing met with delegates of the All-China General Rebel Regiment of the Red Labourers, an organization representing temporary workers. Jiang - who was not only Mao's wife but an important member of the central Cultural Revolution Leading Group expressed her support for abolishing the system of temporary contract work and attacked the Ministry of Labour in a highly-charged speech. ${ }^{37}$ On 2 January 1967, the General Rebel Regiment, the Ministry of Labour, and the official All-China Federation of Trade Unions issued a "common announcement" that during the Cultural Revolution, contract, temporary and outsourced labour

$36 \quad$ Ibid., 649-657.

37 Jiang Qing and Chen Boda, "Jiang Qing Chen Boda yu quanguo hongse laodongzhe zaofan zongtuan daibiao de tanhua", December 26 (1966), in The Chinese Cultural Revolution Database, ed. Song (Hong Kong: Chinese University of Hong Kong, 2006). 
should be abolished. Soon, temporary workers started to rebel against local authorities across broad swathes of China.

Central government leaders now began to worry about the immense cost of making all contract workers permanent employees - the very problem that had led to the expansion of contract work in the first place. Barely a few weeks had passed before the General Rebel Regiment fell victim to a Central Committee order that nationwide mass organizations be dissolved. Then, on 17 February, the Central Committee and the State Council declared that the "common announcement" abolishing contract labour had no legal basis. ${ }^{38}$ The two bodies stated that temporary labour could be acceptable in some cases, and that full resolution of the problem should be deferred until a later stage of the movement. The decision emphasized the political rights of temporary workers to participate in the Cultural Revolution, and those who had been labelled as "counterrevolutionary" by their work units simply for joining a rebel organization were permitted to demand rehabilitation. However, infiltrators from among the "four elements" (landlords, rich peasants, and counterrevolutionary and "rotten elements") should be purged. Temporary workers were not to form their own rebel groups, although they could join the mass organizations of their work units. Participation was contingent on them returning to work in line with their existing contracts.

This dampening of the demands of temporary workers was in line with the wider campaign against "economism", backed by both the central government and the new rebel authorities in Shanghai. In an "urgent notice" issued on 9 January 1967, the Shanghai Rebel Workers' Headquarters listed the restoration of production and the fight against economism as top priorities. Rebellion in the cause of higher wages or other material demands was attacked as risking the ruin of the economy and as an expression of the "reactionary bourgeois line" advocated by "capitalist roaders". ${ }^{39}$ Concessions given by the old party leadership to the workers were derided as a ruse to sabotage the Cultural Revolution. Some scholars have argued that Zhang Chunqiao and other radical leaders who assisted in the takeover in Shanghai were simply using temporary workers for their own political ends and were always set to betray their interests once the new government had been formed. Others have pointed to a silencing of social and economic demands as a result of the campaign against "economism". ${ }^{40}$ In January 1968, the Central Committee and the State Council

38 "Zhonggong zhongyang and guowuyuan, 'Guanyu linshigong, hetonggong, waibaogong de tonggao'”, (17 February 1967), in The Chinese Cultural Revolution Database, ed. Song Yongyi (Hong Kong: Chinese University of Hong Kong, 2006).

39 Li, Geming zaofan niandai, vol. 1, 668-669.

40 Wu, The Cultural Revolution at the Margins, 140-141. 
reaffirmed their stance that the "common announcement" of the previous winter was invalid and that temporary labour should continue to be used. ${ }^{41}$

With this conservative reaction in full swing, prospects for an end to the large-scale use of temporary labour seemed bleak. However, as we shall now see, there was in fact a surprising denouement to the tale, as many temporary workers did become part of the permanent workforce in the early 197os.

Throughout the late Mao period, the official media continued to celebrate workers as "masters of the country". Less visible, but no less important, was the social transformation and expansion of the working class that took place in this period. In 1967, radical leaders had reacted to the push for improved pay and conditions by accusing "revisionist cadres" of corrupting workers with economic demands (in the reform era, the roles would be reversed, with Jiang Qing and the rest of the Gang of Four blamed for wastefully expanding the "iron rice bowl" to temporary workers). ${ }^{42}$ This hostility to workers' demands began to change in 1971, when the State Council issued a decision banning work units from using temporary labour for year-round production tasks. The council also ruled that there should be no more than two and a half million temporary workers engaged, even on short-term or seasonal tasks. As a result of this decision, over eight million temporary workers were able to acquire permanent worker status (as against a total of over nine million in 1971). ${ }^{43}$ The change in policy had a sharply gendered impact, because (as noted earlier), in many cases temporary workers were female relatives of existing permanent workers.

The temporary worker rebels of the early Cultural Revolution had initially seen their demands rejected by the government, but those demands were now belatedly fulfilled. By 1971, no rebel mass organizations existed to pressure the government to improve workers' conditions, but it appears that the old argument - that hiring workers without political and social rights went against the principles of socialism - was eventually persuasive. By that time,

41 Dangdai Zhongguo congshu bianji weiyuanhui, ed., Dangdai Zhongguo de laodongli guanli (Beijing: Zhongguo Shehui Kexue Chubanshe, 199o), 16.

42 Ibid.

43 "Guowuyuan guanyu gaige linshigong, lunhuangong zhidu de tongzhi (gaiyao)", (30 November 1971), in The Chinese Cultural Revolution Database, ed. Song (Hong Kong: Chinese University of Hong Kong, 2006). 
the government had no reason to fear any large-scale labour unrest, because party leadership had already been re-established on the shop floor. A direct link between the rebellion of the temporary workers in late 1966 and the government's change in policy in 1971 is difficult to prove, because no references to the early Cultural Revolution are made in relevant documents. What we can say, however, is that with only five years between the rebellion and the reforms, the temporary workers of the "People's Cultural Revolution" must at least have been in the leadership's minds.

After 1971, the great divide between people inside and outside the system of the "iron rice bowl" remained, but the number of workers in precarious temporary employment was significantly lower in urban China. It is more difficult to assess the impact of the Cultural Revolution on workers who were already in permanent, "iron rice bowl" positions at the outset. While the social prestige of workers was high throughout the last decade of the Mao era, wages were stagnant, rising once - and then only slightly - in 1971. Bonuses, an important part of the pre-1966 salary package, were decried as a "material stimulus" redolent of capitalist economics, and attacked by the rebels as part of Liu Shaoqi's "revisionist line". At the same time, wage cuts and penalties for poor labour performance were abolished; a decision that lowered the pressure on workers, but also made it difficult to enforce discipline in some factories. Young workers who had entered the workforce after 1958 found it more and more difficult to secure promotions and wage increases, resulting in a widening gap between the young and the old. These income restrictions hardly pushed workers to the brink of starvation, but they did make covering daily expenses beyond rations more of a challenge. Workers in the lower ranks, especially those with several children or elderly dependents, had to count every penny to provide for their living expenses.

The stagnation of wages went hand in hand with another, more striking trend: a massive expansion of the urban workforce. In 1966, state-owned enterprises employed 39.3 million people, but by 1976 the figure had risen to 68.6 million. The workforce in the collectively-owned sector expanded from 12.6 to 18.1 million in the same period. ${ }^{44}$

Unsurprisingly, this expansion placed the state's supply systems under renewed strain. In 1972, a year after the decision to include temporary workers in the permanent workforce, the State Council issued a report identifying problems with the grain supply and calling for a limit on the increase of the urban

44 Zhonggong zhongyang shujichu yanjiu lilunzu, ed., Dangqian woguo gongren jieji zhuangkuang diaocha ziliao huibian, 106-107. 
TABLE 8.2 Total number of employees in state-owned and collectively-owned enterprises, 1966-1976 (all figures in millions)

\begin{tabular}{|c|c|c|c|c|c|}
\hline \multirow[t]{3}{*}{ Year } & \multirow{3}{*}{$\begin{array}{l}\text { Total } \\
\text { workforce }\end{array}$} & & & & \\
\hline & & \multicolumn{2}{|c|}{ Ownership by the people } & \multicolumn{2}{|c|}{ Collective ownership } \\
\hline & & Workforce & $\begin{array}{l}\text { Year-on-year } \\
\text { increase }\end{array}$ & Workforce & $\begin{array}{l}\text { Year-on-year } \\
\text { increase }\end{array}$ \\
\hline 1966 & 51.98 & $39 \cdot 34$ & 1.96 & 12.64 & 0.37 \\
\hline 1967 & 53.05 & 40.06 & 0.72 & 12.99 & 0.35 \\
\hline 1968 & 55.04 & 41.70 & 1.64 & 13.34 & 0.35 \\
\hline 1969 & 57.14 & $43 \cdot 35$ & 1.65 & 13.79 & 0.45 \\
\hline 1970 & 62.16 & 47.92 & 4.57 & 14.24 & 0.45 \\
\hline 1971 & 67.87 & 53.18 & 5.26 & 14.69 & 0.45 \\
\hline 1972 & 71.34 & $5^{6.10}$ & 2.92 & 15.24 & 0.55 \\
\hline 1973 & $73 \cdot 37$ & $57 \cdot 5^{8}$ & 1.48 & $15 \cdot 79$ & 0.55 \\
\hline 1974 & $76.5^{1}$ & 60.07 & 2.49 & 16.44 & 0.65 \\
\hline 1975 & 81.98 & 64.26 & 4.19 & $17 \cdot 72$ & 1.28 \\
\hline 1976 & 86.73 & 68.60 & $4 \cdot 34$ & 18.13 & 0.41 \\
\hline
\end{tabular}

SOURCE: ZHONGGONG ZHONGYANG SHIJICHU YANJIU LILUNZU, ED., DANGQIAN WOGUO GONGREN JIEJI ZHUANGKUANG DIAOCHA ZILIAO HUIBIAN (BEIJING, 1983) VOL. 2, 105-106

population and workforce. In response, the government acted to slow the urban expansion. The urban population entitled to grain rations had increased by almost ten million in 1971-1972, a figure that fell to below five million over the subsequent two years. ${ }^{45}$ This smaller increase still represented a burden on the urban supply system and the peasantry, but stable agricultural production meant that it remained a manageable one, in contrast to the failings of the famine years. The rise in the urban population during this period was also partly mitigated by the continued absence from the cities of millions of urban middle-school graduates, who had been "sent down" to the countryside from 1968 onwards to be educated by "poor and lower middle peasants". Many of

45 Zhao Fasheng, Dangdai Zhongguo de liangshi gongzuo (Beijing: Zhongguo shehui kexue chubanshe, 1988), 16o. 
these young people were not permitted to return home for several years, and some never returned to the cities at all.

One striking aspect of the late-Cultural Revolution expansion of the urban workforce was the change in demographics that accompanied it. Available data suggests that the gender and social origin profiles of urban workers underwent a radical shift in this period. The number of female workers and staff in the state-owned enterprises more than doubled; from 7.8 million in 1965 to over 20 million in 1977. Of these 20 million, 8.5 million worked in industry, 2.7 million in the trade, food and service sectors, and 3.3 million in science, education and health. ${ }^{46}$

A survey circulated internally among the official labour unions in 1983 captures some of the major demographic shifts in the workforce during the Cultural Revolution. From a sample of 11 work units in key industrial cities, a picture emerges of a workforce that was larger, younger, more educated and populated with greater numbers of party members than was the case before 1966 . The work units surveyed had a combined staff of over 183,00o, of whom only three per cent had joined before 1949, compared with 37.8 per cent (69,395 people) during the Cultural Revolution. ${ }^{47}$ The breakdown of the newer workers' backgrounds is particularly interesting. Of those recruited between 1966 and 1976, some 1,213 were existing workers, 3,070 were young people leaving vocational training programmes, 4,981 were peasants, 8,403 were demobilized soldiers and a full 18,o39 were "sent down youths" - young people who had been allowed to return from the countryside. ${ }^{48}$

It is noteworthy that "sent down youths" represented a plurality of the new workers. Permission to return to the cities, particularly to a job in a state-owned factory, was a highly desirable outcome for those who had been sent down, and it evidently remained an obtainable one. Demobilized soldiers, the second largest group, were likely to have been given their assignments in most cases more as a reward for service than because of any specific qualifications or education. The omission of "bad elements" - such as landlords and capitalists from the data makes it difficult to determine how these less favoured groups fared. One other obvious point evident in the data is a significant increase in the average new workers' level of education during the Cultural Revolution, compared with the years 1956-1965. The number of new workers who were

46 Guojia tongjiju shehui tongjisi, ed., Zhongguo laodong gongzi tongji ziliao (Beijing: Guojia tongji chubanshe, 1987), 32.

47 Zhonggong zhongyang shujichu yanjiu lilunzu, ed., Dangqian woguo gongren jieji, vol. 2, 1.

48 Ibid., 26-28. This sample is based on 149,995 workers. 
illiterate or who had only primary-school education dropped rapidly, while the proportion who had enrolled in junior high school more than tripled and the intake of workers with senior high-school degrees increased almost fivefold. ${ }^{49}$ For the workers in these 11 sample work units, at least, the reform era narrative of a collapse in the education system during the Cultural Revolution simply does not fit.

By the time the 1983 survey had been compiled, 16.9 per cent of all 149,995 workers for whom data was available were party members, of which the largest group - about 44 per cent - had joined their work units between 1966 and $1976 .{ }^{50}$ Given that less than four per cent of the population at large were CCP members, 16.9 per cent represented a high degree of penetration. There are two possible interpretations of the figure: either workers had a higher "political consciousness" than the general population, or alternatively the CCP had recruited too indiscriminately among this demographic, destroying the elitist "vanguard" status that had long been one of its chief strengths.

Across the 11 sample work units, 23 per cent of the total workforce of 183,611 people were women. The figures show that during the Cultural Revolution, the number of women in the factories more than doubled; from 7,644 in 1965 to 16,944 in 1976. However, a gendered division of labour is still clearly visible in the data. Light industry and the services sector were dominated by women, while heavy industry, shipping and mining were almost exclusively a male preserve. To take the extreme cases, the Shanghai No. 17 Cotton Mill had the highest proportion of female workers at 64 per cent, whereas the Guangzhou Ocean Shipping Company at the other end of the scale had a 99.8 per cent male workforce. The Changchun First Automobile Factory, however, employed 26 per cent women; an unusually high number for that industry. ${ }^{51}$ Data from the Anshan Iron and Steel Company, a well-known national entity, suggests that the division of labour inside the factories changed during the course of the Cultural Revolution, with women moving into formerly male jobs. After 1966, the first women joined its primary steel and chemical production lines. In 1976 , some 26 per cent of new workers were female. ${ }^{52}$

Curiously, the data also shows that - not only during, but also before and after the Cultural Revolution - work units with a high percentage of women tended to have fewer party members than those dominated by men. For example, the Shanghai No. 17 Cotton Mill, Shanghai No. 1 Department Store and Nanjing Radio

\footnotetext{
49 Ibid., 42-25. This sample is based on 149,995 workers.

$50 \quad$ Ibid., vol. 2,6 .

51 Ibid., 18-19.

52 Zhonggong zhongyang shujichu yanjiu lilunzu, ed., Dangqian woguo gongren jieji, vol. 1, 4.
} 
Factory all had very low numbers of party members, compared with heavily male units such as the Guangzhou Ocean Shipping Company, the Zhengzhou Railway Branch Bureau and the Datong Coal Mining Company. This may be a sign that on average, the CCP considered female workers less qualified and less politically reliable as party members, or that a lack of support with childcare and other domestic labour (still considered very much a female preserve) presented a barrier to entry into political life. It is also possible that industrial workers simply enjoyed greater prestige than those in the light industry or services sectors, and that this status difference played out in the party's nomination process. The data from the 1983 survey suggests that some progress was made towards gender equality in the state sector during the Cultural Revolution. Nevertheless, to quote Mao's muchoverused phrase, even with these improved figures, women hardly "held up half the sky".

The Mao era saw striking changes in PRC labour relations. Permanent employment, into which the new peasant workers were recruited in the 1970s, was by far the most desirable form of work. It was also growing rapidly. The workforce in the state-owned enterprises increased from 10 million in 1950 to 68.6 million in 1976, while in the collectively-owned enterprises, the rise was even more rapid; from 1.3 million in 1955 to 18.1 million in 1976. In total, about 75 million people were recruited into the socialist urban workforce during the Mao era. For most, access to the iron rice bowl would have meant a great improvement in their standard of living, especially compared with life "outside the system" or "before liberation". From their perspective, social mobility was a genuine reality.

How, then, are we to assess the hukou household registration system and the other classificatory mechanisms through which the CCP sought to channel and direct social mobility to certain groups? It seems inappropriate simply to dismiss the hukou as a form of medieval "estate", as some have done. Certainly, people unlucky enough to be classified among the "four elements" (landlords, rich peasants, and counterrevolutionary and rotten elements) were treated as outcasts, with few opportunities to improve their situation. However, they accounted for less than ten per cent of the population. For the rest, mobility may not have come easily, but it was achievable - even if a person's prospects were ultimately dependent on the goodwill of the party-state.

The regulation of the centre of social mobility, urban-rural migration and access to jobs or political institutions produced many disturbing outcomes, but 
there was some logic to the CCP's methods, however unsavoury they undoubtedly were. On occasions when the government relaxed controls on rural-urban migration, the number of workers in the cities tended to grow at unsustainable rates, as was the case during the Great Leap and in the early 1970s. The centre was then forced to tighten control again and to "adjust" access to the cities to preserve limited resources. It seems to me that struggles around the rural-urban divide, and inclusion or exclusion based on class status - another major feature of early PRC economic life - were an almost unavoidable consequence of the way the CCP tried to manage resources. In establishing the party-state as a gatekeeper, it ensured that these conflicts would become politicized.

It is ironic that the party leadership under Mao, which so thoroughly crushed the rebellion of temporary workers in 1966, eventually fulfilled most of the demands of this rebel movement in the late Cultural Revolution. However, this victory for labour was short lived. From the mid-198os, the new leadership under Deng Xiaoping began to call not simply for a rollback of the temporary workers' 1970s gains, but for the wholesale destruction of the "iron rice bowl" to improve "economic efficiency" and to subject workers to market relations..$^{53}$ It took until 1998, when the central government dismantled the old state-owned industries through the closure of small units and corporatization of larger ones, for the Dengist vision to be realized. When it was, social unrest took place against privatization, layoffs and the commodification of labour. Nevertheless, in the end, it was workers who ended up on the losing side. Capitalist labour relations were - eventually - enforced.

\section{Bibliography}

Andreas, Joel, Disenfranchised: The Rise and Fall of Industrial Citizenship in China (Oxford: Oxford University Press, 2019).

Brown, Jeremy, City versus Countryside in Mao's China: Negotiating the Divide (Cambridge: Cambridge University Press, 2012).

Chen Yun, "Dongyuan chengshi renkou xiaxiang", in Jianguo yilai zhongyao wenxian xuanbian, vol. 14, ed. Zhongyang wenxian chubanshe (Beijing: Zhongyang wenxian chubanshe, 1992).

Cliver, Robert, Red Silk: Class, Gender, and Revolution in China's Yangzi Delta Silk Industry (unpublished manuscript, Cambridge, MA: forthcoming).

53 For more detail see: Joel Andreas, Disenfranchised: The Rise and Fall of Industrial Citizenship in China (Oxford: Oxford University Press, 2019). 
Dangdai Zhongguo congshu bianji weiyuanhui, ed., Dangdai Zhongguo de laodongli guanli (Beijing: Zhongguo shehui kexue chubanshe, 1990).

Frazier, Mark W., The Making of the Chinese Industrial Workplace: State, Revolution and Labor Management (Cambridge: Cambridge University Press, 2002).

Guojia tongjiju shehui tongjisi, ed., Zhongguo laodong gongzi tongji ziliao (Beijing: Guojia tongji chubanshe, 1987).

"Guowuyuan guanyu gaige linshigong, lunhuangong zhidu de tongzhi (gaiyao)", (30 November 1971), in The Chinese Cultural Revolution Database, ed. Song Yongyi (Hong Kong: Chinese University of Hong Kong, 2006).

Jiang Qing and Chen Boda, "Jiang Qing Chen Boda yu quanguo hongse laodongzhe zaofan zongtuan daibiao de tanhua", December 26 (1966), in The Chinese Cultural Revolution Database, ed. Song (Hong Kong: Chinese University of Hong Kong, 2006).

Jin Chongji ed., Zhou Enlai zhuan, vol. 4 (Beijing: Zhongyang wenxian chubanshe, 1998).

Li Xun, Geming zaofan niandai: Shanghaiwenge yundong shigao, vol. 1 (Hong Kong: Oxford University Press, 2015).

Lu Yu, Xin Zhongguo renkou wushi nian, vol. 1 (Beijing: zhongguo renkou, 2004).

Liu Shaoqi "Guanyu liang zhong laodong zhidu he liang zhong jiaoyu zhidu", YGYL, 19 (1991).

Luo Pinghan, Da qianxi:1961-1963 nian de chengzhen renkoujing jian (Nanning: Guangxi renmin chubanshe, 2003).

Mao Tse-tung, Ausgewählte Werke, vol. v (Beijing: Verlag für fremdsprachige Literatur, 1978).

Perry, Elizabeth, Challenging the Mandate of Heaven: Social Protest and State Power in China (Armonk: Cambridge University Press, 2001).

Perry, Elisabeth, "Masters of the Country? Shanghai Workers in the Early People's Republic", in Dilemmas of Victory: The Early Years of the People's Republic of China, ed. Jeremy Brown and Paul G. Pickowicz (Cambridge, MA: Harvard University Press, 2007), 59-79.

"Shangyebu dangdai Zhongguo liangshi gongzuo bianjibu", ed., Dangdai Zhongguo liangshi gongzuo shiliao, vol. 1 (Baoding: Hebei sheng gongxiaoshe Baoding yinshuachang yinshua, 1989).

Sicular, Terry, "Grain Pricing: A Key Link in Chinese Economic Policy", Modern China, 14, no. 4 (1988): 451-486.

Walder, Andrew, Chang Ch'un-ch'iao and Shanghai's January Revolution (Ann Arbor: Cambridge University Press, 1978).

Wemheuer, Felix, Famine Politics in Maoist China and the Soviet Union (New Haven: Yale University Press, 2014).

Wemheuer, Felix, A Social History of Maoist China: Conflict and Change, 1949-1976 (Cambridge: Cambridge University Press, 2019). 
Wu, Yiching, The Cultural Revolution at the Margins: Chinese Socialism in Crisis (Cambridge, MA: Harvard University Press, 2014).

Yuan Yongxi ed., Zhongguo renkou zonglun (Beijing: Zhongguo caizhengjingji chubanshe, 1991).

Zhao Fasheng, Dangdai Zhongguo de liangshi gongzuo (Beijing: Zhongguo shehui kexue chubanshe, 1988).

Zhongguo geming bowuguan, ed., Zhongguo gongchandang dangzhang huibian (Beijing: Renmin chubanshe, 1979).

Zhou Enlai, "Guanyu zhishifenzi de gaizao wenti", in Jianguo yilai zhongyao wenxian xuanbian, vol 2., ed. Zhongyang wenxian chubanshe (Beijing: Zhongyang wenxian chubanshe, 1992).

"Zhonggong Zhongyang guanyu zhua geming, cu shenchan de shitiao guiding (cao'an)", (9 December 1966), in The Chinese Cultural Revolution Database, ed. Song Yongyi, (Hong Kong: Universities Service Centre for China Studies, The Chinese University of Hong Kong, 2006).

"Zhonggong zhongyang and guowuyuan, 'Guanyu linshigong, hetonggong, waibaogong de tonggao', (17 February 1967), in The Chinese Cultural Revolution Database, ed. Song Yongyi (Hong Kong: Chinese University of Hong Kong, 2006).

Zhonggong zhongyang shujichu yanjiushi lilunzu, ed., Dangqian woguo gongren jieji zhuangkuang diaocha ziliao huibian, vol. 2 (Beijing: Zhonggong zhongyang dangxiao chubanshe, 1983).

Zhongguo shehui kexueyuan and zhongyang dang'anguan, ed., 1958-1965 Zhonghua renmin gongheguo jingji dang'an ziliao xuanbian. Laodong jiuye he shouru fenpei juan (Beijing: Zhongguo caizheng jungji chubanshe, 2011).

"Zhonghua renmin gongheguo nongye bu jihuasi", ed., Zhongguo nongcun jingji tongji daquan 1949-1986 (Beijing: Nongye chubanshe, 1989). 